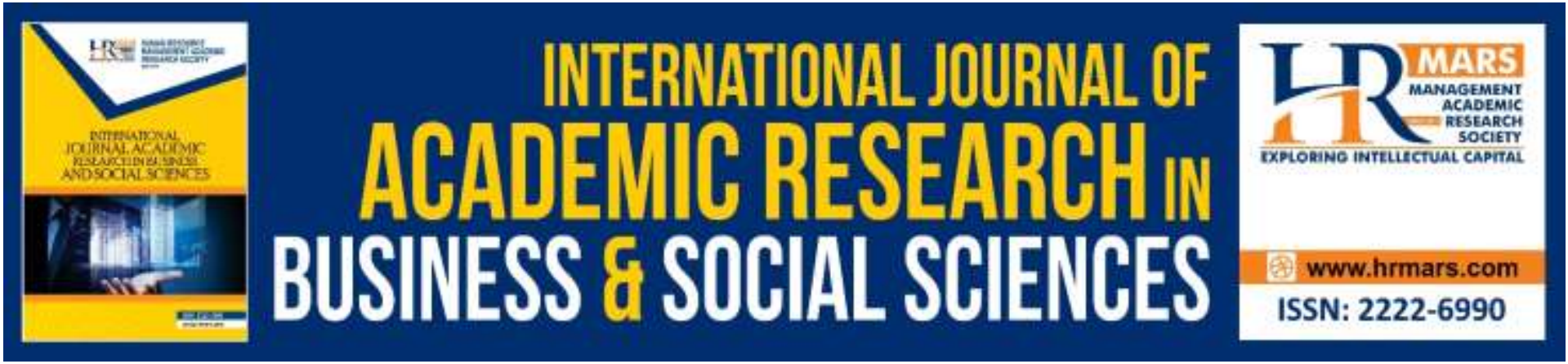

\title{
Leveraging on Social Media as a Communication Channel for Improving Services of the Government of Malaysia
}

Nur Farhana Abdullah, Devika Nadarajah, Raja Nerina Raja Yusof, Ahmad Shaharudin Abdul Latiff

To Link this Article: http://dx.doi.org/10.6007/IJARBSS/v9-i9/6409

DOI: $10.6007 /$ IJARBSS/v9-i9/6409

Received: 23 July 2019, Revised: 10 August 2019, Accepted: 30 August 2019

Published Online: 24 September 2019

In-Text Citation: (Abdullah, Nadarajah, Yusof, \& Latiff, 2019)

To Cite this Article: Abdullah, N. F., Nadarajah, D., Yusof, R. N. R., \& Latiff, A. S. A. (2019). Leveraging on Social Media as a Communication Channel for Improving Services of the Government of Malaysia. International Journal of Academic Research in Business and Social Sciences, 9(9), 1140-1155.

\section{Copyright: (C) 2019 The Author(s)}

Published by Human Resource Management Academic Research Society (www.hrmars.com)

This article is published under the Creative Commons Attribution (CC BY 4.0) license. Anyone may reproduce, distribute, translate and create derivative works of this article (for both commercial and non-commercial purposes), subject to full attribution to the original publication and authors. The full terms of this license may be seen at: http://creativecommons.org/licences/by/4.0/legalcode

\section{Vol. 9, No. 9, 2019, Pg. 1140 - 1155}

Full Terms \& Conditions of access and use can be found at http://hrmars.com/index.php/pages/detail/publication-ethics 


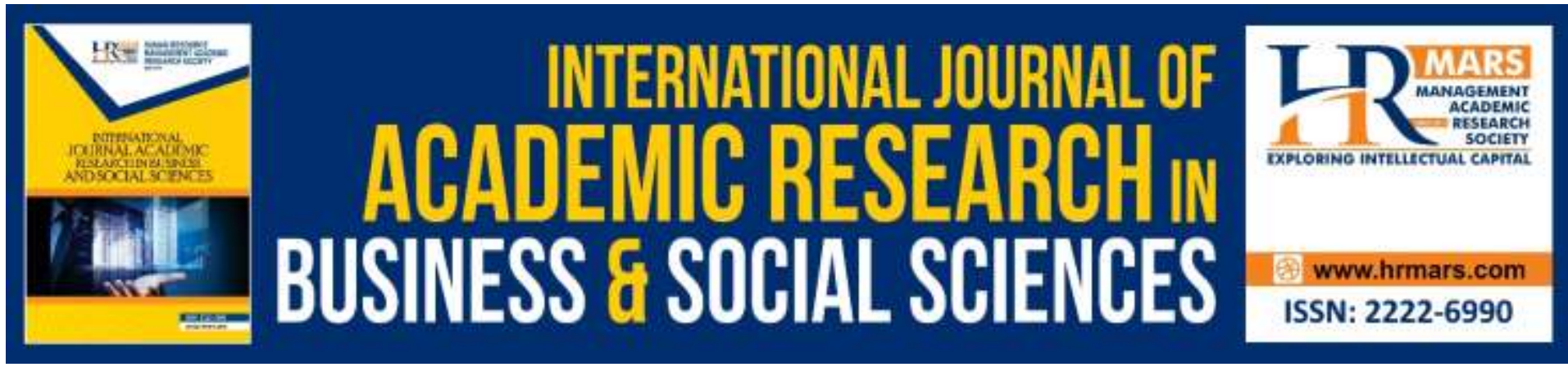

\title{
Leveraging on Social Media as a Communication Channel for Improving Services of the Government of Malaysia
}

\author{
Nur Farhana Abdullah ${ }^{1 *}$, Devika Nadarajah², Raja Nerina Raja \\ Yusof ${ }^{3}$, Ahmad Shaharudin Abdul Latiff ${ }^{4}$ \\ ${ }^{1 * 2,4}$ Putra Business School, 43400 UPM Serdang, Malaysia \\ ${ }^{3}$ Department of Management and Marketing, Faculty of Economics and Management, \\ Universiti Putra Malaysia, 43400 Serdang, Malaysia, ${ }^{1 *}$ Institute of Advancement Studies, \\ University of Malaya, 50603 Lembah Pantai, Malaysia
}

\begin{abstract}
In today's competition, the private and public sector is taking social media to another level towards achieving their purposes, whether to improve profitability of the company or to improve organizational performance. Ubiquitous and innovative ICTs provide different communication channels for the public to give feedbacks on the services given the public sector. As such, social media provides an opportunity to gather feedbacks and responses towards improving services. The purpose of this paper is to give a background on leveraging social media to improve services in the Malaysian government sector. Based on the study background, observations and content analysis on the social media pages were carried out for the purpose of the study. It is understood that leveraging social media does have an advantage to give insights for successful social media implementation and can give a positive organizational effect to the departments.
\end{abstract}

Keywords: Social Media, Services, Government, Public Service, Business

\section{Introduction}

The government of Malaysia has introduced several transformational plans to develop and reduce the gap in economic, social and cultural divide inequality between citizens (Jabatan Perdana Menteri Report, 2010). The transformational plans started in 1991 with Vision 2020 aimed for Malaysia to be a developed nation. As Malaysia strive to be a developed nation, various transformation plans were put in place to improve the citizens quality of life, which somehow affected the public sector's service delivery. The Public Service Department (Jabatan Perkhidmatan Awam) made public service reforms and developed several strategies and programmes for the public sector to improve their service delivery. These public service reforms aimed to improve service performance among government staffs and inculcate an excellent working culture among government officials. Apart from those strategies, the crucial factors for the government to understand and improve their services are through 
collecting public opinions, feedbacks and active participation between the government and citizens.

Service delivery quality is still the main concern to both private and public sectors which are still striving to maintain a competitive advantage in the marketplace (Tan, Hamid \& Chew, 2017). In 1991, the Public Service Department had developed guidelines and programmes to improve the quality of public service delivery to ensure excellent services are delivered to the public. Although there are guidelines, programmes and strategies to improve and enhance service in the public sectors, service delivery quality still stays as an agenda that needs close attention. An improvement on service delivery is backed up by the thousands number of complaints that were received by the Public Complaint Bureau (Biro Pengaduan Awam). In 2013 the total number of complaints received was 9879 and in 2017, the total number was 4625.

Service delivery has been a central subject and emphasized by the Malaysian government towards their civil servants since the inception of the Government Transformation Plan in 1991 and it is an ongoing agenda to this date. In 2017, the Chief Secretary to the Government (Ketua Setiausaha Negara) Tan Sri Dr. Ali bin Hamsa, in his annual speech at the Excellence Services Award to all civil servants, have addressed the issue of service quality among civil servants and urged them to deliver excellent services to the citizens. The Chief Secretary had urged all Heads of Department to create at least one social media account that act as a channel for receiving information and views from the staffs and public. According to the Chief Secretary, the use of social media is likely to complement excellent service delivery as the social media can be used as means of communication between the staffs and citizens as well as getting feedback on the services.

The Ministries in Malaysia are using social media to disseminate information to the mass public through their official social media accounts which are Facebook, Twitter, Instagram and YouTube. Bonsón, Royo, \& Ratkai (2014) in their study on Facebook practices in Western European Municipalities reported the citizen engagement is low. Many governments perceive the social media platform as complementary channels to disseminate information, rather than creating bidirectional communication (Gao \& Lee, 2017). Observations done in 2017 shows there are similarities in the social media pages owned by the Ministries in Malaysia pertaining to the bidirectional communication. There are queries left by the followers in the reviews and recommendation section in the Facebook pages of the Ministries are left unanswered by the admin of the social media pages.

Nowadays, social media is seen as an important tool to enhance communication between different parties such as between subordinates, staffs and citizens. The function of social media has grown since its first inception as a sharing platform to a wider purpose which is to create better communication among society.

\section{Social Media as Communications Channels in the Government}

The government agenda is to improve the quality of public services that are displayed on their official websites. There is a policy visible in the government websites called eParticipation, which aims to improve transparency and public participation. The policy states that using information and communication technology channels, they could get the citizens involved in the decision-making process and policy development. Earlier research on identifying significant variances between service channel selections by Anthopoulos (2014) mentioned the citizen feedbacks are collected using two channel which are traditional and non- 
traditional channels. According to Anthopoulos (2014), traditional channels are defined as office visits, face-to-face contacts, public consultation, feedback forms and opinion polls and the non-traditional channels refer to the new digital media such as mobile applications, social media and text messaging. His study found digital divide, user satisfaction, nature of transaction and security and privacy does have an impact on using e-government and digital divide has the highest impact.

The government is using new digital media such as social media to disseminate information to the broader public, making a rich set of government information available to stakeholders and individual citizens and allowing massive participation of users, often called "crowdsourcing" (Chun, Shulman, Sandoval, \& Hovy, 2010). However, an examination on the Malaysian Ministries social network sites shows is there less interaction or engagement from the citizens in their social media pages. This issue could be studied from the perspective of activities types in social media platforms and the content of the posts, what are the topics covered and whether the activities promoted by the government sector reflect unidirectional information distribution or bidirectional exchange, discussion, dialogue and collaboration (Bonsón et al., 2014). Bidirectional interactions as explained by Bonsón et al., (2014); Rains \& Brunner (2015) are frequent communication and feedback between government representatives and the public. Nevertheless, the observation done on the Ministries Facebook pages, it is a one-way exchange without much or less participation from their followers. This scenario suggests the Facebook pages are more towards promoting the Ministries activities rather than having two-way exchanges or dialogues with their followers.

The performance and research findings may provide decision makers in the government with insights that active participation, collaboration and exchanges between the government and the citizens that could lead to successful social media adoption and positive organizational effect to the departments.

\section{Public Service Reforms and Introducing Social Media}

In Malaysia, public service reforms are based on international best practices. A study by Xavier, Siddiquee, \& Mohamed (2016) mentioned it has been applied across the public sector and it is responsible for improving public service delivery. However, the public service reforms are deemed not effective thus, a Government Transformation Plan was introduced to replace the previous public service reforms (Xavier, 2014; Xavier, Siddiquee, \& Mohamed, 2016). The Government Transformation Plan bring along an expectation of building a performance culture among government employees. In the service industry, the subject matter of service quality remains crucial to both private and public sector as they are striving to maintain a competitive advantage in the marketplace (Tan, Hamid, \& Chew, 2017). A guideline to improve quality in public service delivery has been developed by the Public Service Department since 1991. The guideline included seven programs as a strategy to improve service quality among government staffs which are Quality Suggestion System, Quality Process System, Quality Checking System, Quality Day, Quality Feedback System, Quality Information System and Quality Slogan.

The main aim of the seven programs developed by the Public Service Department is to develop a driver of an excellent working culture among public service staffs. As such, there are various activities carried out to improve service quality in the public sector. It is to ensure the services given to the public are at an excellent level. The stakeholders or citizens are given the opportunity to give feedback on the services provided by the public sector. Thus, many 
feedback channels have been setup by the government for the public to give their feedback. The Public Complaint Bureau (Biro Pengaduan Awam) produces statistical reports on an annual basis of the service performances of the government agencies in Malaysia. The report is generated based on the complaints given by the public through various channels, who are using the services given by the government and its agencies and is made available for public downloading and viewing since the year 2000. The report demonstrates that public services are still a primary concern due to the high number of complaints received from the public each year. A compilation list for five-years from Public Complaint Bureau reports the total number of complaints made through various type of channels from the year 2013 to 2017 as in Table 1.

Table 1: Lists and Number of Complaints Received Through Various Channels from 2013 to 2017 (Source: Public Complaint Bureau reports)

\begin{tabular}{|l|l|c|c|c|c|c|}
\hline \multirow{2}{*}{ No } & \multirow{2}{*}{ Channel } & \multicolumn{5}{c|}{ Number of Complaints/Year } \\
\cline { 3 - 7 } & & 2017 & 2016 & 2015 & 2014 & 2013 \\
\hline 1 & SISPAA Website Form & 2172 & - & - & - & - \\
\hline 2 & Rakyat Responz & 417 & 46 & - & - & - \\
\hline 3 & E-mail \& Online Complaint Forms & 399 & 3903 & 3963 & 4185 & 5537 \\
\hline 4 & Walk-In & 562 & 598 & 638 & 696 & 667 \\
\hline 5 & Letter, Fax \& Department Counter & 374 & 571 & 631 & 609 & 792 \\
\hline 6 & Stakeholder & 245 & 185 & - & - & - \\
\hline 7 & Telephone & 227 & 383 & 368 & 419 & 611 \\
\hline 8 & Proactive Programs & 95 & 555 & 568 & 1103 & 1594 \\
\hline 9 & MASJA Complaint & 27 & 107 & 122 & 97 & 499 \\
\hline 10 & SMS & 17 & 41 & 54 & 21 & 1 \\
\hline 11 & Pos Malaysia & 17 & 22 & 19 & 30 & - \\
\hline 12 & Social Network (FB, Twitter, Blog) & 3 & 18 & 20 & 21 & 4 \\
\hline 13 & Forward & 2 & - & - & - & - \\
\hline 14 & 1MOCC & 37 & 65 & 2 & 6 & 33 \\
\hline 15 & KIOSK & - & - & 1 & - & - \\
\hline 16 & Newspapers & - & - & 2 & 2 & - \\
\hline 17 & UTC & - & - & - & 7 & 137 \\
\hline 18 & Others & - & - & - & 3 & 3 \\
\hline 19 & Electronic Malaysia & - & - & - & - & 1 \\
\hline & TOTAL & 4594 & 6494 & 6388 & 7199 & 9879 \\
\hline
\end{tabular}

Table 1 displays the number of complaints received by the government and its agencies that have been collated by the Public Complaint Bureau for five years from 2013 to 2017. For the past five years, the most popular channel used by the public to address their complaint was through email and online complaint form. Although SISPAA (Sistem Pengurusan Aduan Awam) Website Form is a new system and only introduced in 2017, it appears to have the highest number of usages by the public. Social network sites such as Facebook, Twitter and Blogs owned by the government and its agencies are the least preferred feedback complaint channel by the public as there are only a few complaints made through that channel. This 
may imply that the public does not participate nor engage actively in the social network sites owned by the government and its agencies. According to the report by the bureau, the highest number of complaints received by the government agencies are related to poor service quality which includes counter and telephone services. The interesting fact that the public uses social media to give comments although social media was initially not meant for feedback purposes.

Social media platform is actively used by Malaysians. It is reported by The Statistics Portal (2019) that Malaysia has more than 23 million social network users. In the complaint report by Public Complaint Bureau, $0.24 \%$ social media users contribute to the total number of feedback and complaints (refer to Table 1). Considering the earlier purpose of social media are for self-presentation and self-disclosure (Kaplan \& Haenlein, 2010), there is an opportunity for the government to use the avenue to improve their services. As such, this leads to a bigger picture on the communication channel of new digital media or social media used by the citizens to give feedback on the service delivery of the government and their agencies. Anthopoulos (2014) stated that multi-channel public service delivery shows certain channels have specific purposes. According to Anthopoulos (2014), citizens prefer nontraditional for information retrieval while the traditional channel is for individual problem solving, and this finding indicates that it is imperative for e-government channel to provide information to citizens. Citizens who live the urban area have been found to prefer using egovernment compared to the traditional channel. The demographic area of urban and nonurban citizens does affect the preference of different channels.

The purpose of using social media has evolved from self-presentation and selfdisclosure to interacting and giving feedback. The usage of social media also has increased with the number of its users, with the rapid growth of internet users. The numbers of internet users around the world have increased from 1024 million in 2005 to 3896 million in 2018 (The Statistic Portal, 2019). As such, the usage of e-government has also increased due to the larger population of digital literate users. The increased population of digital literate citizens will also escalate the usage of new media, and these circumstances show that the government need to participate in using the new media to interact with the citizens.

\section{The Value of Social Media Data to Improve Services}

Data from social media can be used for various purposes. Developed countries such as the United States of America (USA) are using data gathered from social media for various purposes such as politics, emergency management and healthcare. In the Western part of the world, most of the research that has been done creates an opportunity for research in developing countries such as South East Asia to benefit from using social media data. The information and data inserted by the users including publicly expressing their sentiments into their social media pages contributed to the vast amount of data in the world wide web (Janssen \& Kuk, 2016; Piryani, Madhavi, \& Singh, 2017).

These days, using advanced technologies in harnessing and analyzing the vast amount of data are often viewed as impossible in the past, are now being mobilized through individual human or organizational decision-making process (Elish \& Boyd, 2018). The challenges and opportunities of social media had been conceptualised earlier in a seminal article by Kaplan \& Haenlein (2010) that it represents a revolutionary new trend and should be the interests of companies. According to George, Haas, \& Pentland (2014), social media is one of the many sources that produces big data. Social media has other functions instead of exchanging views 
and information. The data harnessed from social media can contribute to the organisations to improve their business outcomes using the latest technology tools.

In recent years, management research has encouraged exploring the potential and opportunities for new theories and practices of big data (George, Haas, \& Pentland, 2014). (George, Haas, \& Pentland, 2014). Big data produces social media data (Rogge, Agasisti, \& De Witte, 2017). According to Rogge, Agasisti, \& De Witte (2017), big data offers new opportunities to measure efficiency in public sectors' performances. Leading users in big data from both private and public sectors who successfully captured the potential of big data will beat their competitors (Brown, Chui, \& Manyika, 2011; Rogge, Agasisti, \& De Witte (2017). Mergel (2012); Mossberger, Wu, \& Crawford (2013) stated that harnessing big data from the social media followers posts, create opportunities for the government to improve its services and operations. A study by Oliveira \& Welch (2013) on mapping government social media mentioned that social media is rapidly becoming a significant instrument in the USA local governments. They that stated social media is used to disseminate information, gathering feedback, improve service quality and internal work collaboration. It is indeed providing benefit for the public sector to improve their service quality, rather than them having relied individually on the traditional channel of attaining public feedbacks. Williamson (2014) in exploring models of government practices in the era of big data and digitalisation found that, the public services have economicly and socially innovated. They are using information from new data sources created in social media. However, Panagiotopoulos, Bowen, \& Brooker (2017) argued that the value of social media data is still not known and how it can impact policy making.

It is noted that the enormous amount of information and new sources created from social media give the opportunity to harness and analyse the opinion or sentiment from the public for better-improved services. This opportunity does not only benefit the private sector but also the government at all levels. Although the private and public sector have different purposes but somehow using this new technology gives advantage towards their capabilities to achieve the mission and vision of the organization.

\section{Social Media and Service Delivery in the Malaysian Government}

Malaysia transformational journey began with a long-term plan known as the New Economic Policy (Dasar Ekonomi Baru was also known as DEB) in the year 1971 with growth equality as the primary objective of the plan. The main overall goal of the Malaysian Government Transformation Plan was to create unity. The creation of unity was utilised by four main strategies which were to reduce dispositions of economic, social and cultural gaps among citizens. A two-pronged strategy was implemented to eradicate poverty and restructuring communities. In the year 1991, Dr. Mahathir Mohamed the 4th Prime Minister of Malaysia introduced Vision 2020. Vision 2020 drove the transformational journey towards a developed nation with six main goals consisting of economics, politics, social, spiritual, psychological and cultural (Jabatan Perdana Menteri, 2010). The first phase of Vision 2020 started with the National Development Policy (Dasar Pembangunan Nasional) in the year 1991-2000 and emphasized on the eradication of hardcore poverty to reduce general poverty. The second phase of Vision 2020 namely National Vision Policy (Dasar Wawasan Negara) started from the year 2001-2010 and emphasized on sustainable growth and strengthening of economic resilience and creating a united and equitable society. The third phase which is the final plan of Vision 2020 implemented under the New Economic Model (Model Ekonomi Baru) launched 
in 2010 covering the period from 2011 to 2020. The New Economic Model's main aim is to improve the quality of life in society. The model emphasized on three dimensions which are high income, sustainability, and inclusiveness, and this model is targeting the lowest income earners. The third phase has four pillars that emphasized the transformation of the country: Government Transformation Programme, Economic Transformation Programme, Political Transformation Programme and Rural Transformation Programme. A summary of the Government Transformation Plans and its main objectives is shown in Table 2.

Table 2 - Summary of the Government Transformation Plans (source: retrieved from Economic Planning Unit - EPU)

\begin{tabular}{|c|c|c|c|}
\hline $\begin{array}{l}\text { Government } \\
\text { Transformation } \\
\text { Plan }\end{array}$ & Plan & Main Objective & Outcome \\
\hline $\begin{array}{l}\text { New Economic } \\
\text { Policy (Dasar } \\
\text { Ekonomi Baru) }\end{array}$ & $\begin{array}{l}\text { (1971-1990) } \\
\text { National Unity }\end{array}$ & $\begin{array}{l}\text { Growth with } \\
\text { Equality } \\
\text { 2-pronged } \\
\text { strategy: } \\
\text { 1. To eradicate } \\
\text { poverty } \\
2 \text {. } \\
\text { Restructuring } \\
\text { communities }\end{array}$ & $\begin{array}{l}\text { Reducing } \\
\text { dispositions of } \\
\text { economic, } \\
\text { social, and } \\
\text { cultural gaps } \\
\text { among } \\
\text { citizens. }\end{array}$ \\
\hline \multirow[t]{3}{*}{ Vision 2020} & $\begin{array}{l}\text { (1991 - 2000) Phase 1: } \\
\text { National Development Policy } \\
\text { (Dasar Pembangunan } \\
\text { Nasional) } \\
\text { Maintaining the } \\
\text { fundamental principles of } \\
\text { the New Economic Policy } \\
\text { (NEP), namely growth with } \\
\text { equality. }\end{array}$ & $\begin{array}{l}\text { Growth with } \\
\text { Equality to } \\
\text { Eradicate } \\
\text { Poverty }\end{array}$ & \multirow{3}{*}{$\begin{array}{c}\text { Economics } \\
\text { Politics } \\
\text { Social } \\
\text { Spiritual } \\
\text { Psychological } \\
\text { Cultural }\end{array}$} \\
\hline & $\begin{array}{l}\text { (2001 - 2010) Phase 2: } \\
\text { National Vision Policy } \\
\text { (Dasar Wawasan Negara) }\end{array}$ & $\begin{array}{l}\text { Sustainable } \\
\text { Growth; } \\
\text { Economic } \\
\text { Resilience; } \\
\text { United and } \\
\text { Equitable } \\
\text { Society }\end{array}$ & \\
\hline & $\begin{array}{l}\text { (2011-2020) Phase 3: } \\
\text { New Economic Model } \\
\text { (Model Ekonomi Baru) }\end{array}$ & $\begin{array}{l}\text { Improve the } \\
\text { Quality of Life } \\
\text { of the Sciety }\end{array}$ & \\
\hline
\end{tabular}




\begin{tabular}{|l|l|l|l|}
\hline $\begin{array}{c}\text { Government } \\
\text { Transformation } \\
\text { Plan }\end{array}$ & \multicolumn{1}{|c|}{ Plan } & Main Objective & \multicolumn{1}{|c|}{ Outcome } \\
\hline & $\begin{array}{l}\text { 4 Pillars: } \\
\text { 1. Government } \\
\text { Transformation Programme } \\
\text { 2. Economic Transformation } \\
\text { Programme } \\
\text { 3. Political Transformation } \\
\text { Programme }\end{array}$ & $\begin{array}{l}\text { (high income, } \\
\text { sustainability } \\
\text { and } \\
\text { inclusiveness } \\
\text { that } \\
\text { 4. Rural Transformation } \\
\text { Programme }\end{array}$ & $\begin{array}{l}\text { the bottom 40 } \\
\text { percent income } \\
\text { group) }\end{array}$ \\
& & \\
\end{tabular}

In the year 2009, the establishment of the Performance Management and Implementation Unit is known as PEMANDU (Unit Pengurusan Prestasi dan Pelaksanaan) in the Prime Minister's Office was to oversee and ensure the National Transformation Programmes (NTP) are in the right path, to ensure that the country will have a resilient, sustainable and inclusive economy. According to the Government Transformation Plan Annual Report 2017 by PEMANDU, the plan has produced the desired results with increased performance in the targeted sectors such as Foreign Direct Investment, increased income disparity, reducing poverty rate, increased development in rural areas such as better access to treated water, electricity and road connectivity and better connection on urban transportation system. Xavier, Siddiquee, \& Mohamed (2016) analyzed on the Government Transformation Plan (GTP) and reported that PEMANDU has indeed successfully driven the GTP based on best practices and best-fit approach. The government's main objective of GTP to improve society's quality of life has somehow made the public sector employees to work harder to increase their service delivery quality.

Every Ministry in Malaysia own more than one social media accounts, and the common ones are Facebook (FB), Twitter, Instagram, and YouTube, as shown in Table 3. 
Table 3 - Ministries in Malaysian Government with Social Media Accounts (Source: The Ministries official social media pages taken as at November 2017)

\begin{tabular}{|c|c|c|c|c|c|}
\hline $\begin{array}{l}\text { Name of } \\
\text { Ministry }\end{array}$ & $\begin{array}{l}\text { FB } \\
\text { L: Likes } \\
\text { F: } \\
\text { Follow } \\
\text { ers } \\
\end{array}$ & $\begin{array}{l}\text { Overall } \\
* \text { in } \mathrm{FB} \\
\text { page } \\
\text { (public } \\
\text { ratings) }\end{array}$ & Twitter & $\begin{array}{l}\text { YouTube } \\
\text { No. of } \\
\text { Subscriber } \\
\text { s }\end{array}$ & Instagram \\
\hline $\begin{array}{l}\text { Ministry of Higher } \\
\text { Education (MoHE) }\end{array}$ & $\begin{array}{l}210,435 \\
(L) \\
210,229 \\
\text { (F) }\end{array}$ & NA & $\begin{array}{l}\text { Tweets: } 5,534 \\
\text { Followers: } \\
2596 \\
\quad \text { Likes: } 720\end{array}$ & 105 & NA \\
\hline $\begin{array}{r}\text { Ministry of Education } \\
\text { (MOE) }\end{array}$ & $\begin{array}{l}554,669 \\
\text { (L) } \\
552,719 \\
\text { (F) }\end{array}$ & NA & $\begin{array}{c}\text { Tweets: } 16.2 \mathrm{~K} \\
\text { Followers: } \\
26.2 \mathrm{~K} \\
\text { Likes: } 2,878\end{array}$ & NA & $\begin{array}{c}\text { Posts: } 940 \\
\text { Followers: } \\
3,982\end{array}$ \\
\hline $\begin{array}{r}\text { Ministry of Finance } \\
\text { (MOF) }\end{array}$ & $\begin{array}{l}109,938 \\
(L) \\
109,627 \\
\text { (F) }\end{array}$ & NA & $\begin{array}{c}\text { Tweets: } 6,397 \\
\text { Followers: } \\
\text { 17.7K } \\
\text { Likes: } 29\end{array}$ & NA & $\begin{array}{l}\text { Posts: } 546 \\
\text { Followers: } \\
2,941\end{array}$ \\
\hline $\begin{array}{r}\text { Ministry of Home } \\
\text { Affairs (KDN) }\end{array}$ & $\begin{array}{c}288,697 \\
\text { (L) } \\
287,812 \\
\text { (F) }\end{array}$ & & $\begin{array}{c}\text { Tweets: } 10.3 \mathrm{~K} \\
\text { Followers: } \\
\text { 329K } \\
\text { Likes: } 1,265\end{array}$ & 145 & $\begin{array}{l}\text { Posts: } 841 \\
\text { Followers: } \\
\text { 24.9K }\end{array}$ \\
\hline $\begin{array}{r}\text { Ministry of Works } \\
(\mathrm{MOW})\end{array}$ & $\begin{array}{l}24,478 \\
(L) \\
24,548 \\
(F) \\
\end{array}$ & NA & $\begin{array}{c}\text { Tweets: } 33.2 \mathrm{~K} \\
\text { Followers: } \\
\text { 9491K }\end{array}$ & 62 & $\begin{array}{c}\text { Posts: } 309 \\
\text { Followers: } \\
\quad 777\end{array}$ \\
\hline $\begin{array}{r}\text { Ministry of Urban } \\
\text { Well-Being, Housing } \\
\text { and Local Government } \\
(\text { MUHLG) }\end{array}$ & $1,683(\mathrm{~L})$ & $3.9 / 5$ & $\begin{array}{c}\text { Tweets: } 11.8 \mathrm{~K} \\
\text { Followers: } \\
12.1 \mathrm{~K} \\
\text { Likes: } 1,339\end{array}$ & NA & $\begin{array}{c}\text { Posts: } 627 \\
\text { Followers: } \\
1,295\end{array}$ \\
\hline $\begin{array}{l}\text { Ministry of Human } \\
\text { Resources (MOHR) }\end{array}$ & $\begin{array}{l}148,456 \\
(L) \\
148,278 \\
(F)\end{array}$ & $4.3 / 5$ & $\begin{array}{r}\text { Tweets: } \\
\text { 5,277K } \\
\text { Followers: } \\
15.5 \mathrm{~K} \\
\text { Likes: } 975\end{array}$ & NA & NA \\
\hline $\begin{array}{l}\text { Ministry of } \\
\text { International Trade } \\
\text { and Industry (MITI) }\end{array}$ & $\begin{array}{l}17,830 \\
(L) \\
17,867 \\
(F)\end{array}$ & NA & $\begin{array}{c}\text { Tweets: } 15.7 \mathrm{~K} \\
\text { Followers: } \\
33.6 \mathrm{~K} \\
\text { Likes: } 1,709\end{array}$ & 129 & $\begin{array}{l}\text { Posts: } 206 \\
\text { Followers: } \\
\quad 588\end{array}$ \\
\hline $\begin{array}{r}\text { Ministry of } \\
\text { Communication and } \\
\text { Multimedia (KKMM) }\end{array}$ & $\begin{array}{l}36,274 \\
\text { (L) } \\
36,354 \\
\text { (F) }\end{array}$ & NA & $\begin{array}{c}\text { Tweets: } \\
\text { 2,409K } \\
\text { Followers: } \\
7,115 \mathrm{~K}\end{array}$ & 11 & NA \\
\hline
\end{tabular}




\begin{tabular}{|c|c|c|c|c|c|}
\hline $\begin{array}{l}\text { Name of } \\
\text { Ministry }\end{array}$ & $\begin{array}{l}\text { FB } \\
\text { L: Likes } \\
\text { F: } \\
\text { Follow } \\
\text { ers }\end{array}$ & $\begin{array}{l}\text { Overall } \\
* \text { in FB } \\
\text { page } \\
\text { (public } \\
\text { ratings) }\end{array}$ & Twitter & $\begin{array}{l}\text { YouTube } \\
\text { No. of } \\
\text { Subscriber } \\
\text { s }\end{array}$ & Instagram \\
\hline & & & Likes: 45 & & \\
\hline $\begin{array}{r}\text { Ministry of Tourism } \\
\text { and Culture (MOTAC) }\end{array}$ & $\begin{array}{l}77,271 \\
(L) \\
77,205 \\
(F)\end{array}$ & NA & $\begin{array}{c}\text { Tweets: } \\
\text { 9.617K } \\
\text { Followers: } \\
\text { 2,046K } \\
\text { Likes: } 472 \\
\end{array}$ & NA & $\begin{array}{c}\text { Posts: } 1,579 \\
\text { Followers: } \\
4,356\end{array}$ \\
\hline $\begin{array}{r}\text { Ministry of Defence } \\
\text { (MOD) }\end{array}$ & $\begin{array}{c}551,088 \\
(\mathrm{~L}) \\
548,285 \\
(\mathrm{~F}) \\
\end{array}$ & $4.5 / 5$ & $\begin{array}{c}\text { Tweets: } 16.7 \mathrm{~K} \\
\text { Followers: } \\
21.7 \mathrm{~K} \\
\text { Likes: } 1,011 \\
\end{array}$ & 414 & $\begin{array}{l}\text { Posts: } 605 \\
\text { Followers: } \\
\quad 24\end{array}$ \\
\hline $\begin{array}{r}\text { Ministry of Natural } \\
\text { Resources and } \\
\text { Environment (NRE) }\end{array}$ & $\begin{array}{l}2,786(\mathrm{~L}) \\
2,871(\mathrm{~F})\end{array}$ & NA & $\begin{array}{c}\text { Tweets: } \\
\text { 2,774K } \\
\text { Followers: } \\
\text { 4,066K } \\
\text { Likes: } 820\end{array}$ & 216 & $\begin{array}{l}\text { Posts: } 641 \\
\text { Followers: } \\
\quad 384\end{array}$ \\
\hline $\begin{array}{r}\text { Ministry of Science, } \\
\text { Technology and } \\
\text { Innovation (MOSTI) }\end{array}$ & $\begin{array}{l}50,950 \\
\text { (L) } \\
50,958 \\
\text { (F) }\end{array}$ & NA & $\begin{array}{c}\text { Tweets: } \\
\text { 3,930K } \\
\text { Followers: } \\
\text { 5,069 } \\
\text { Likes: } 1,272\end{array}$ & 95 & $\begin{array}{c}\text { Posts: } 1,385 \\
\text { Followers: } \\
2,635\end{array}$ \\
\hline $\begin{array}{r}\text { Ministry of Domestic } \\
\text { Trade, Co-operatives } \\
\text { and Consumerism } \\
\text { (KPDNKK) }\end{array}$ & $\begin{array}{c}344,571 \\
\text { (L) } \\
344,289 \\
\text { (F) }\end{array}$ & NA & $\begin{array}{c}\text { Tweets: } 12,8 \mathrm{~K} \\
\text { Followers: } \\
\text { 19,6K } \\
\text { Likes: } 820\end{array}$ & 116 & $\begin{array}{c}\text { Posts: } 2,085 \\
\text { Followers: } \\
\text { 5,309 }\end{array}$ \\
\hline $\begin{array}{ll}\text { Ministry of } \begin{array}{l}\text { Health } \\
(\mathrm{MOH})\end{array}\end{array}$ & $\begin{array}{l}876,671 \\
(L) \\
874,356 \\
(F)\end{array}$ & NA & $\begin{array}{l}\text { Tweets: } 21,2 \mathrm{~K} \\
\text { Followers: } \\
22,5 \mathrm{~K} \\
\text { Likes: } 1,427\end{array}$ & 1127 & $\begin{array}{l}\text { Posts: } 560 \\
\text { Followers: } \\
80.2 \mathrm{~K}\end{array}$ \\
\hline $\begin{array}{r}\text { Ministry of Federal } \\
\text { Territories (KWP) }\end{array}$ & $\begin{array}{l}71,167 \\
\text { (L) } \\
70,858 \\
\text { (F) }\end{array}$ & NA & $\begin{array}{l}\text { Tweets: } 473 \\
\text { Followers: } 33 \\
\text { Likes: } 1\end{array}$ & 5 & $\begin{array}{l}\text { Posts: } 250 \\
\text { Followers: } \\
752\end{array}$ \\
\hline $\begin{array}{r}\text { Ministry of Women, } \\
\text { Family and Community } \\
\text { Development } \\
(\text { KPWKM) }\end{array}$ & $\begin{array}{l}174,981 \\
\quad(L) \\
173,832 \\
(F)\end{array}$ & $5 / 5$ & $\begin{array}{l}\text { Tweets:20.5K } \\
\text { Followers: } \\
\text { 15.7K } \\
\text { Likes: } 1,305\end{array}$ & 18 & $\begin{array}{l}\text { Posts: } 2,128 \\
\text { Followers: } \\
4,268\end{array}$ \\
\hline
\end{tabular}




\begin{tabular}{|c|c|c|c|c|c|}
\hline $\begin{array}{l}\text { Name of } \\
\text { Ministry }\end{array}$ & $\begin{array}{l}\text { FB } \\
\text { L: Likes } \\
\text { F: } \\
\text { Follow } \\
\text { ers }\end{array}$ & $\begin{array}{c}\text { Overall } \\
* \text { in FB } \\
\text { page } \\
\text { (public } \\
\text { ratings) }\end{array}$ & Twitter & $\begin{array}{l}\text { YouTube } \\
\text { No. of } \\
\text { Subscriber } \\
\text { s }\end{array}$ & Instagram \\
\hline $\begin{array}{r}\text { Ministry of Transport } \\
\text { (MOT) }\end{array}$ & $\begin{array}{l}9,957(\mathrm{~L}) \\
9,905(\mathrm{~F})\end{array}$ & NA & $\begin{array}{l}\text { Tweets: } \\
\text { 5,102K } \\
\text { Followers: } \\
\text { 11.9K } \\
\text { Likes: } 577\end{array}$ & 27 & $\begin{array}{l}\text { Posts: } 122 \\
\text { Followers: } \\
969\end{array}$ \\
\hline $\begin{array}{r}\text { Ministry of Agriculture } \\
\& \text { Agro-Based Industry } \\
\text { (MOA) }\end{array}$ & $\begin{array}{c}47,424 \\
(L) \\
48,066 \\
(F)\end{array}$ & NA & $\begin{array}{l}\text { Tweets: } \\
\text { 5,129K } \\
\text { Followers: } 10 \mathrm{~K} \\
\text { Likes: } 596\end{array}$ & 268 & NA \\
\hline $\begin{array}{l}\text { Ministry of Plantation } \\
\text { Industries and } \\
\text { Commodities (KPPK) }\end{array}$ & $\begin{array}{c}11,167 \\
(\mathrm{~L}) \\
11,221 \\
(\mathrm{~F})\end{array}$ & $\begin{array}{l}4.5 / \\
5\end{array}$ & $\begin{array}{c}\text { Tweets: } 10,1 \mathrm{~K} \\
\text { Followers: } \\
2,191 \mathrm{~K} \\
\text { Likes: } 3,658 \mathrm{~K}\end{array}$ & NA & NA \\
\hline $\begin{array}{r}\text { Ministry of Rural and } \\
\text { Regional Development } \\
(\text { KKLW) }\end{array}$ & $\begin{array}{l}101,914 \\
(\mathrm{~L}) \\
101,751 \\
(\mathrm{~F})\end{array}$ & NA & $\begin{array}{c}\text { Tweets: } \\
\text { 1,495K } \\
\text { Followers: } \\
2,159 \mathrm{~K} \\
\text { Likes: } 235 \\
\end{array}$ & 17 & $\begin{array}{l}\text { Posts: } 2,344 \\
\text { Followers: } \\
10 \mathrm{~K}\end{array}$ \\
\hline $\begin{array}{r}\text { Ministry of Energy, } \\
\text { Green Technology and } \\
\text { Water (KeTTHA) }\end{array}$ & $\begin{array}{c}13,452 \\
(\mathrm{~L}) \\
13,434 \\
(\mathrm{~F}) \\
\end{array}$ & NA & $\begin{array}{c}\text { Tweets: } 42 \\
\text { Followers: } 131\end{array}$ & 22 & $\begin{array}{l}\text { Posts: } 350 \\
\text { Followers: } \\
393\end{array}$ \\
\hline $\begin{array}{r}\text { Ministry of Youth and } \\
\text { Sports (KBS) }\end{array}$ & $\begin{array}{c}100,433 \\
(\mathrm{~L}) \\
99,970 \\
(\mathrm{~F}) \\
\end{array}$ & NA & $\begin{array}{c}\text { Tweets: } 23,3 \mathrm{~K} \\
\text { Followers: } \\
\text { 21.8K } \\
\text { Likes: } 708\end{array}$ & 571 & NA \\
\hline
\end{tabular}

Table 3 represents twenty-three (23) Ministries in the Malaysian Government and the type of social media accounts owned by them. The social media accounts are Facebook, Twitter, Instagram and Youtube. The number of followers, likes, tweets, subscribers and posts for the social media are recorded as at 30 November 2017. Facebook and Twitter are the most popular social media account owned by the Ministries, followed by Instagram and YouTube but not all ministries own Instagram and Youtube account. The Ministry with the greatest number of followers is the Ministry of Health $(\mathrm{MoH})$ with 552,719 followers and Ministry of Natural Resources has the least number of followers with 2,786. Few of the Facebook accounts displayed a public rating where the followers can rate and give feedback on the services or facilities related to the Ministries. The lowest rating is one (1) star, and the highest rating is five (5) star. As for Twitter, the Ministry of Federal Territories has the least tweets of 473 and the Ministry of Works has the most tweets with 33,200. The Ministers do have their social media accounts, and some are linked to the Ministry official social media 
accounts. Observation on the Ministers personal social media account shows that they received more likes, tweets and comments from the citizens. These personal social media accounts gained more likes and tweets compared to the social media accounts owned by the Ministry. The citizens might feel that it is easier to engage and interact directly with the person of authority. Active citizen engagement and interaction is important for the government to obtain information on how to improve their services.

For social media to be used effectively, it must be measured. Sentiment is the user's emotional state, his or her judgment or evaluation of a certain person or topic, or the intended emotional communication (i.e., the emotional effect the sender wishes to have on the receiver) (Stieglitz \& Dang-Xuan, 2013). It is essential to understand the meaning of sentiment before describing sentiment analysis. Sentiment analysis aims to analyse people's sentiments, opinions, attitudes and emotions, towards elements such as topics, products, individuals, organizations and services (Serrano-Guerrero, Olivas, Romero, \& Herrera-Viedma, 2015; Khalid, Pahi, \& Ahmed, 2016).

Generally, in this study, the sentiment analysis is a tool to measure the sentiment or opinions created by the citizens in social media. The social media includes FB, Twitter, Instagram and YouTube whereby analysis of sentiment is used to evaluate positive and negative tones including strong and weak emotions of the users. These tones are then measured using a tool to identify the strength of the emotions written by the social media users.

A review study by Mäntylä, Graziotin, \& Kuutila, (2018); Madrid, Ahmed, \& Kumar, (2019) on the evolution of sentiment analysis research reported that the most recent research topics in 2014-2016 had more focus on social media such as Twitter and Facebook. According to Mäntylä, Graziotin, \& Kuutila, (2018), most of the research done on opinion mining and sentiment analysis is dominated by the field of computer science and engineering. As such, it is imperative that other fields of research that contribute to the area of sentiment analysis to get a broader understanding. An analytical mapping study carried out by Piryani, Madhavi, \& Singh (2017) defines sentiment analysis and opinion mining as a natural language processing task that uses algorithmic formulation to identify opinionated content and categorize it as having "positive" "negative" or "natural" polarity. The research area mapped by the authors suggests the field of Computer Science dominated the opinion mining and sentiment analysis research area which is similar with the findings of a review study done by Mäntylä, Graziotin, \& Kuutila, (2018). Piryani, Madhavi, \& Singh (2017) emphasized that opinion of others or "what other people think" as important during decision-making process. Opinions of users have two-pronged consequences which are (1) helping individuals taking informed decisions and (2) helping organizations in identifying customer attitudes or opinions about their product or services. A study by Zavattaro, French, \& Mohanty (2015) on sentiment analysis on local government tweets in the United States discovered that local governments still push information to followers in social media, but positive tone of tweets can encourage active participations of citizens in social media.

There are abundant of studies on opinion mining or sentiment analysis had been concentrated on the science-based research dominated by Computer Science. This may be due to the fact that researchers are continuing to study the various algorithm or tools to mine opinion and analysis the sentiments in the internet. While the research done in social science started with mining the opinions on politics and emergency management, the literature on using such tools to improve public service delivery is still scant. Hence, there is a need for 
management research on social media and sentiments and its influence on the service delivery to the public.

\section{Conclusion}

Social media study in the services area particularly in the government sector gives an opportunity to be further researched. Although the study in similar subject is found in the western countries, it is still lacking in other parts of the world especially in Malaysia focusing on the government sectors. Previous research by prominent scholars had discovered the niche essential to services area that technology is important to elevate the organizations services' performance, with social media as one of the top channels. To extend social media effectiveness, sentiments from posts are measured and analyzed and this allows the organization to identify the type of tones produced by the citizens. This study will be further enhanced with data collected from the field. The findings will be documented and reported. The significance of the findings of this study may be viewed within the perspectives of both researchers and practitioners. From the researchers' perspective, the study could advance the body of literature and knowledge on service delivery by integrating social media and service delivery in one framework. The proposed framework could improve the quality of service delivery and decision making of the government sector. Meanwhile from the practitioners' perspective, this study will benefit managers at the government agencies to understand the importance and usage of social media technology specifically for more informed decision making. Managers will be able to explore more and better ways to help their departments or sectors maximize their current resources to be more efficient and costeffective. Policy makers will benefit from analyzing sentiments of citizens in their decisionmaking processes. This review should create impetus for the need to conduct further research to determine the real impact of using new technology such as social media towards improving services in the Malaysian public sector context.

\section{Acknowledgement}

The author would like to acknowledge the Ministry of Higher Education, Malaysia for sponsoring the student's PhD study and her employer University of Malaya for supporting her PhD journey.

\section{Corresponding Author}

Nur Farhana Abdullah ${ }^{1}$

Putra Business School

Universiti Putra Malaysia

43400 UPM Serdang

Malaysia

Email: nurfarhana.phd16@grad.putrabs.edu.my

\section{References}

Anthopoulos, C. R. L. (2014). Interactions With E-Government, New Digital Media And Traditional Channel Choices: Citizen-Initiated Factors. Transforming

Government: People, Process and Policy, 8(3), 398-419. https://doi.org/10.1108/TG-08-2013-0026

Bonsón, E., Royo, S., \& Ratkai, M. (2014). Facebook Practices in Western European 
Municipalities.Administration \& Society, 49(3), 320-347.

https://doi.org/10.1177/0095399714544945

Brown, B., Chui, M., \& Manyika, J. (2011). Are You Ready For The Era Of 'Big Data'? McKinsey Quarterly, 4(October), 24-35. https://doi.org/00475394

Chun, S. A., Shulman, S., Sandoval, R., \& Hovy, E. (2010). Government 2.0: Making Connections Between Citizens, Data And Government. Information Polity, 15(1-2), 1-9. https://doi.org/10.3233/IP-2010-0205

Elish, M. C., \& Boyd, D. (2018). Situating Methods In The Magic Of Big Data and Al. Communication Monographs, 85(1), 57-80. https://doi.org/10.1080/03637751.2017.1375130

Gao, X., \& Lee, J. (2017). E-government Services And Social Media Adoption: Experience Of Small Local Governments in Nebraska state. Government Information Quarterly, 34(4), 627-634.

https://doi.org/10.1016/j.giq.2017.09.005

George, G., Haas, M. R., \& Pentland, A. (2014). Big Data and Management. Academy of Management Journal, 57(2), 321-326.

https://doi.org/10.5465/amj.2014.4002

Jabatan Perdana Menteri. (2010). Annual Report. Retrieved from Government Transformation Programme. Report, 1-264.

Jabatan Perdana Menteri. (2010, Januari 28). Pelan Halatuju-Ringkasan Eksekutif. Retrieved from Program Transformasi Kerajaan. Unit Pengurusan Prestasi Dan Pelaksanaan (PEMANDU), 1-44.

Janssen, M., \& Kuk, G. (2016). Big and Open Linked Data (BOLD) In Research, Policy, And Practice. Journal of Organizational Computing and Electronic Commerce, 26(1-2), 3-13. https://doi.org/10.1080/10919392.2015.1124005

Kaplan, A. M., \& Haenlein, M. (2010). Users Of The World, Unite! The Challenges And Opportunities Of Social Media. Business Horizons, 53(1), 59-68. https://doi.org/10.1016/j.bushor.2009.09.003

Khalid, N., Pahi, M. H., \& Ahmed, U. (2016). Loosing your best talent: Can leadership retain employees? The dilemma of the banking sector of Hyderabad Sindh, Pakistan: A mediation investigation. International Review of Management and Marketing, 6(3), 608-616.

Mäntylä, M. V., Graziotin, D., \& Kuutila, M. (2018). The Evolution Of Sentiment Analysis-A Review Of Research Topics, Venues, And Top Cited Papers. Computer Science Review, $27,16-32$.

https://doi.org/10.1016/j.cosrev.2017.10.002

Madrid, D., Ahmed, U., \& Kumar, R. (2019). Examining the Impact of Classroom Environment on Entrepreneurship Education: Case of a Private University in Bahrain. Journal of Entrepreneurship Education, 22(1), 1-8.

Mergel, I. (2012). The Social Media Innovation Challenge In The Public Sector. Information Polity, 17(3-4), 281-292. https://doi.org/10.3233/IP-2012-000281

Mossberger, K., Wu, Y., \& Crawford, J. (2013). Connecting Citizens And Local Governments? Social Media And Interactivity In Major U.S. Cities. Government Information Quarterly, 30(4), 351-358.

https://doi.org/10.1016/j.giq.2013.05.016

Oliveira, G. H. M., \& Welch, E. W. (2013). Social Media Use In Local Government: Linkage Of 
Technology, Task, And Organizational Context. Government Information Quarterly, 30(4), 397-405.

https://doi.org/10.1016/j.giq.2013.05.019

Panagiotopoulos, P., Bowen, F., \& Brooker, P. (2017). The Value Of Social Media Data: Integrating Crowd Capabilities In Evidence-Based Policy. Government Information Quarterly, 34(4), 601-612. https://doi.org/10.1016/j.giq.2017.10.009

Piryani, R., Madhavi, D., \& Singh, V. K. (2017). Analytical Mapping Of Opinion Mining And Sentiment Analysis Research During 2000-2015. Information Processing and Management, 53(1), 122-150. https://doi.org/10.1016/j.ipm.2016.07.001

Rains, S. A., \& Brunner, S. R. (2015). What Can We Learn About Social Network Sites By Studying Facebook? A Call And Recommendations For Research On Social Network Sites. New Media \& Society, 17(1), 114-131. https://doi.org/10.1177/1461444814546481

Rogge, N., Agasisti, T., \& De Witte, K. (2017). Big Data And The Measurement Of Public Organizations ' Performance And Efficiency : The State-Of-The-Art. https://doi.org/10.1177/0952076716687355

Serrano-Guerrero, J., Olivas, J. A., Romero, F. P., \& Herrera-Viedma, E. (2015). Sentiment Analysis: A Review And Comparative Analysis Of Web Services. Information Sciences, 311, 18-38. https://doi.org/10.1016/j.ins.2015.03.040

Stieglitz, S., \& Dang-Xuan, L. (2013). Emotions and Information Diffusion in Social MediaSentiment of Microblogs and Sharing Behavior. Journal of Management Information Systems, 29(4), 217-248. https://doi.org/10.2753/MIS0742-1222290408

Tan, L. H., Hamid, S. R., \& Chew, B. C. (2017). Exploring Manager's Perspective Of Service Quality Strategies in Malaysian Banking Industry. Journal of Strategic Marketing, 25(1), 31-48. https://doi.org/10.1080/0965254X.2015.1076878

Williamson, B. (2014). Knowing Public Services : Intermediaries And Algorithmic Governance In Public Sector Reform. https://doi.org/10.1177/0952076714529139

Xavier, J. A. (2014). A Diagnostic Approach to Performance Management: The Case of the Performance Management and Delivery Unit of Malaysia. International Journal of Public Administration, 37(13), 970-979. https://doi.org/10.1080/01900692.2014.944991

Xavier, J. A., Siddiquee, N. A., \& Mohamed, M. Z. (2016). The Government Transformation Programme of Malaysia: A Successful Approach To Public Service Reform. Public Money and Management, 36(2), 81-87. https://doi.org/10.1080/09540962.2016.1118927

Zavattaro, S. M., French, P. E., \& Mohanty, S. D. (2015). A Sentiment Analysis Of U . S . Local Government Tweets: The Connection Between Tone And Citizen Involvement. Government Information Quarterly, 32(3), 333-341.

https://doi.org/10.1016/j.giq.2015.03.003 